\title{
EXPORT PRICES AND EXCHANGE RATES
}

Irving B. Kravis

NBER and University of Pennsylvania

Robert E. Lipsey

NBER and Queens College, CUNY

Ellot R.J. Kalter

Board of Governors of the Federal Reserve System

Work1ng Paper Nio. 182

NATIONAL BUREAU OF ECONOMIIC RESEARCH, InC. 261 Madison Avenue

New York, N.Y. 10016

\section{July 1977}

Preliminary; Not for Ouotation

NBER working papers are distributed informally and in limited number for comments only. They should rot be quoted without written permission.

This report has not undergone the review accorded official NBER publications; in particular, it has not yet been submitted for approval by the Board of Directors. 
EXPORT PRICES AND EXCHANGE RATES ${ }^{*}$

Irving B. Kravis, Robert E. Lipsey, Eliot R.J. Kalter

\section{Introduction}

The changing competitive position of the United States in international trade is the net result of many influences operating on the internal prices of the United States and its chief competitors and on the exchange rates between their currencies and the currencies of other countries. Both monetary and real factors, and both cyclical and secular influences affect the competitive position of the country.

The present paper is intended to make a modest contributicn to an understanding of one small but important link in this complicated chain of interacting factors. It is a link that has often been ignored because strong simplifying assumptions have until very recently, usually been made about it. We refer to the relation of exchange rate changes, export prices, and domestic prices. During the last few years a number of attempts have been made to examine the extent to which exchange rate changes were "passed through"; that is, the extent to which a given depreciation in the U.S. dollar, for example, resulted in a corresponding decline in the price of U.S. exports in foreign currencies. ${ }^{*}$ However, the possibility that a change in the exchange rate might also alter the relationship between tine export price and the domestic price of a given product, expressed in the same currency, has been almost completely ignored. The assumption made,

*This paper draws on earlier studies carried out with support from the vational Science Foundation and the U.S. Department of Comnerce. The new price indexes and special calculations reported in this paper were performed under a contract with the U.S. Department of State. The views reported here do not necessarily reflect those of any of these agencies.

${ }^{\star *}$ S.P. Magee, "Currency Contracts, Pass-through, and Devaluation," Brookings Papers on Economic Activity, 1:1973. W.H. Branson, "The Effects of the 1971 Currency Realigrments," Brookings Papers on Economic Activity, 1:1972. S.Y. Kwack, "The Effects of Foreign Inflation on Domestic Prices and the Relative Price Advantages of Exchange Rate Changes," Discussion Paper No. 35, November 21, 1973, Diviston of Incernational Finance, Board of Governors of the Federal Reserve System. L. Schwartz and Lorenzo Perez, "Survey Evidence on the Pass-tirough of Smithsonian Foreizn Currency Revaluation on Dollar Prices of U.S. Imports," Department of Comerce and Treasury. 
implicitly by most past writers in the theory of international trade and more recently explicitly by advocates of the monetary approach to the balance of payments, has been that the "law of one price" applies to shipments destined for home markets and for foreign markets.

\section{Reasons for Deviations from the Law of one Price}

For the prices of internationally traded goods to be identical in different markets, transport costs must be zero or equal for each product for all origins to each destination, or each traded good must have only one source of supply. If these conditions are not met, there must be some differences in prices of internationally traded goods either at each destination for goods with different origins or at the various points of origin for goods with a single destination.

There are, however, more weighty reasons -- both static and dynamic -- for expecting departures from tine law of one price. A static circunstance giving rise to price discrimination between destinations is that in at least some sectors there are oligopolistic firms facing different elasticities of demand at home and in each foreign market; profit maximizing behavior would lead such firms to charge lower prices in the markets characterized by more elastic demand. The possibility of price differences among different exporters from the same or different countries is abetted by the existence of product differentiation both in terms of physical characteristics relating to appearance and performance, and in terms of various service elements such as before-and-after-sale advice and service, credit terms and speed of delivery. " oligopoly strategies aimed at maintaining a certain price position relative to rivals may produce price discrimination when the constellation of rivals differs from market to market or when the exchange rates of different

\footnotetext{
* See I.B. Kravis and R.E. Lipscy, "Export and Domestic Prices Under Inflation and Exchange Rate Movements," National bureau of Fconomic Rescarch lorkfng Paper 176, May 1977 and Price Competicluesess in lorld l'rade (New York: National burcau of
} 
destination countries move differently with respect to the oligopolist's home currency. Such behavior would be warranted if the oligopolist regards his long run profit maximization in a market as being jeopardized by a loss of market share (a form of capital).

In adition, dynamic factors associated with changes in competitive advantage and changing market shares make it possible for one source of supply to be selling at lower prices over protracted periods of time. Selling at a low price is, after all, the traditional way of breaking into a market and expanding market sinares. Shifts in trade shares in individual product classes and broad groups of products are continually occurring. In the decade of the 1960s, for example, the share of Japan in "world" manufactured exports rose by more than 70 percent while that of the U.K. dropped by more than a fourth and that of the U.S. by more than a tenth. If such shifts are prolonged and frequent, disequilibrium situations in which markets have not fully adjusted to changes in comparative advantage may be the norm rather than the exception. The files of the U.S. International Trade Commission (formerly the Tariff Commission) and of like bodies in other countries are full of claims that foreign sellers are undercutting domestic producers in home markets, and such claims are not infrequently accompanied by expanding foreign shares in domestic markets.

Lack of knowledge, uncertainty regarding the reliability of new suppliers, the reluctance to give up a satisfactory relationship with customary suppliers and commitments to a given type of equipment because of previous purchases or stocks

\footnotetext{
"The share comparisons are for the years 1960 and 1970; the "world" consists of the 14 major industrial countries. See U.S. Department of Commerce, International Economic Indicators and Competitive Trends, June 1976, p. 57.
} 
of spare parts may all explain the failure of buyers to respond immediately to price differences. They may explain too why it may be necessary for price differences of a substantial and/or prolonged character to exist if sellers hope to overcome the inertia of buyers in patronizing customary sources.

There are, therefore, reasons for believing that there will be notable departures from the uniformity of prices and also, since the causal conditions alter through time, in the uniformity of price changes. The evidence on this point is far from voluminous, but it tends to emerge from almost any careful set of international price comparisons.

Evidence of price differences for exports of different origin

Documentation of the existence of substantial differences in the export prices of different countries may be found in an earlier National Bureau study dealing with the international price competitiveness for manufactured metals and metal products (Kravis and Lipsey, 1971). While some differences were found in all 6 of the 2-digit SITC* categories included in the study, the largest difierences were in iron and steel (SITC Division 67).** Japanese prices averaged 30 percent

* Standard International Trade Classification, Revised, Statistical Papers, Series M, No. 34 (New York: United Nations, 1961).

**

Relative prices of each iron and steel product in this comparison are weighted by the importance of each product in 1963 exports of OECD countries. The country composition of the OECD has varied; the statistics in the source cited refer to 18 European countries and the U.S., Canada, and Japan. 
less than those of the U.S., German prices 24 percent less and the U.K. prices 22 percent less. Table 1 shows frequency distributions of price differences from the U.S. For individual 3- and 4-digit SITC categories falling within the iron and steel (SITC 67), non-electrical machinery (SITC 71) and electrical machinery (SITC 72) divisions. For iron and steel, the individual differences, though clustered around the average cited above, were as large as 43 percent for Japan in the case of iron and steel wire (SITC 67) and 40 percent for Germany in the cases of bars and rods (SITC 673.2) and tube and pipe fittings (SITC 678.5). These differences persisted more or less over the entire period covered by the study, 1953-64. The period was one in which the U.S. share in the iron and steel exports of the 21 OECD countries declined from 19 percent to 10 percent and that of the U.K. from 14 percent to 9 percent, while the German share rose from 12 to 18 percent and the Japanese share from 5 to 14 percent. Similar, though less dramatic differences in prices and changes in shares were found in non-electrical machinery and electrical machinery. " For this period, at least, notable and even substantial price differences persisted while the low price sellers gradually expanded their market shares and the high priced sellers saw their shares contract.

Evidence of differences in the time to time movement of export prices of comparable goods from different countries.

Using a combination of data reported upon in earlier work (1971) and official German and U.S. export price data, we are able to compare German and U.S. export prices for machinery and equipment (SITC 7) over the period 1954-75 (see

\footnotetext{
* The data referred to in this and the two preceding sentences may be found in I.B. Kravis and R.E. Lipscy, p=ice Comnetitiveness in lorld Trare (New York: National Eureau of Econonic Rescarch, 1971), in Table 2.4 and Appendix Tables $B-1, \Sigma-45$, and $E-1$.
} 
Table 1

Frequency Distribution of Percentage Differences of Export Prices of

U.X.. Gormany and Japan from U.S. Export Prices for 3- and 4-digit SITC Categories, 1963

\section{Percentage difference from U.S. price}

67 Iron and Steel

$$
-40 \text { to }-49.99
$$$$
-30 \text { to }-39.99
$$$$
-2.0 \text { to }-29.99
$$$$
-10 \text { to }-19.99
$$$$
-5 \text { to }-9.99 \ldots
$$

Number of categoriag compared

71 Machinery other than eleotxio

$$
\begin{aligned}
& -30 \text { to }-39.99 \\
& -20 \text { to }-29.99 \\
& t-101 \text { to }-19.99 \\
& -5 \text { to }-9.99 \\
& -0 \text { to }+4.99 \\
& +5 \text { to }+9.99 \\
& +10 \text { to }+19.99
\end{aligned}
$$

Number of categories compared

72 Electric Machinery

$$
-30 \text { to }-39.99
$$$$
-20 \text { to }-29.99
$$$$
-10 \text { to }-19.99
$$$$
-5 \text { to }-9.99
$$$$
-0.1 \text { to }-4.99
$$$$
0 \text { to }+4.99
$$$$
+5 \text { to }+9.99
$$$$
+10 \text { to }+29.99
$$$$
+20 \text { to }+29.99
$$

Number of categories compared
Number of 3- and 4-digit categories. U.K. Germany . Japan

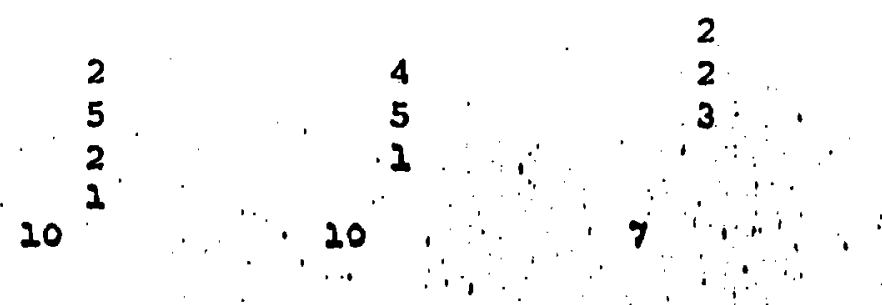

27

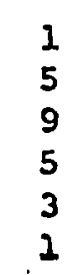

24

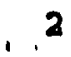

2

1.

4

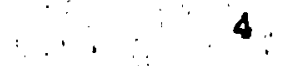


Table 2). From 1954 to 1969 when the D.M./dollar exchange rate was relatively stable (varying within a 7 percent range) the annual ratios of German to U.S. export prices, both taken in dollar terms, varied within a 10 percent range. Beginning in 1969, however, the mark began to appreciate, and most of its rise was passed through to German dollar export prices. The German/U.S. export price ratio was 45.5 percent higher in 1975 than in 1969; the German export price in DM increased by 44.3 percent and the $\$ / D M$ rate by 59.7 percent compared to a rise in U.S. export prices of 58.4 percent. As this implies, there is very little correlation between the changes in German and U.S. export prices when both are expressed in dollars.

\section{Price discrimination}

There is also persistent evidence that price discrimination by sellers to different markets is quite common in international trade. References to such discrimination are continually appearing in the business and financial press, and occasionally there is an official finding of discriminatory pricing.

Although information about domestic pricing policies was not solicited in the National Bureau study referred to above, about half of the 121 U.S. sellers that provided price information nevertheless indicated what their pricing policies were. Of these, about half stated that their foreign and domestic prices differed." The information obtained from these and other sellers and buyers, including some

*For example, it was recently reported that the common Market fined a glass producer for selling insulating fiber glass in Germany at a price 40 percent higher than that charged in the Benelux countries and another firm for maintaining music record prices in Germany 50 percent higher than in France. It was also reported that a fruit company was selling bananas in rich Comon Market countries at twice the price charged in poorer ones. New York Times, 17 January 1976.

Differences attributable to higher packaging expenses for preparing goods for overseas shipment were not counted as price differences. 


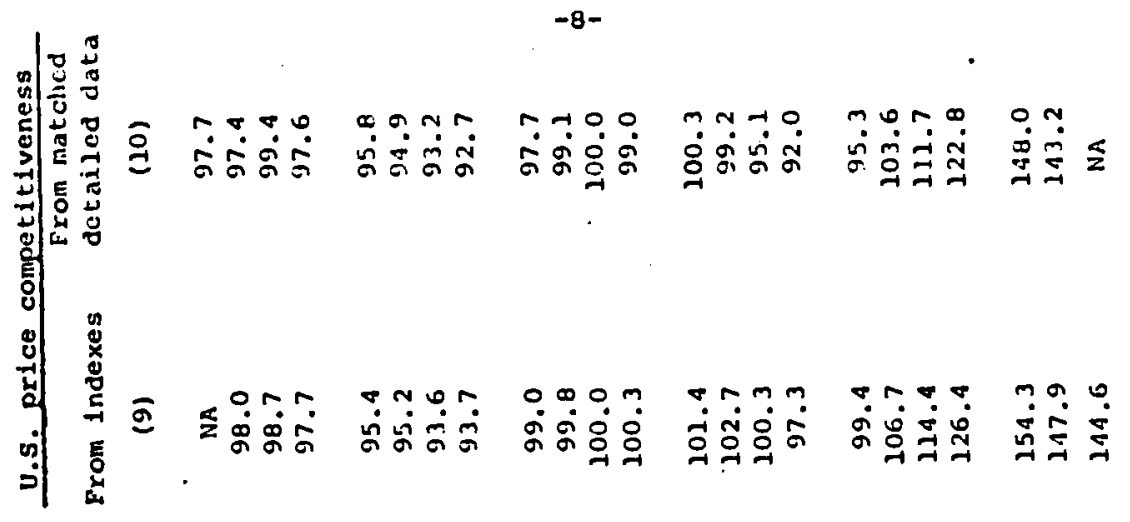

กับ

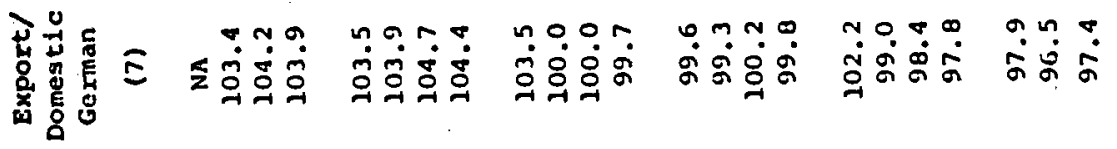

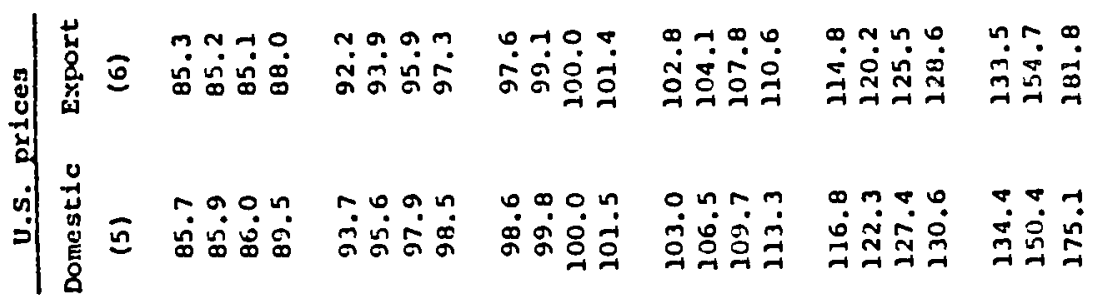

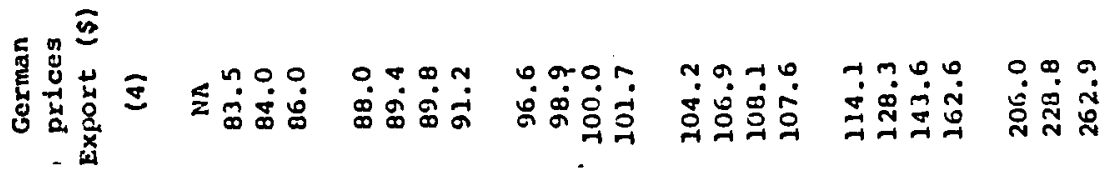

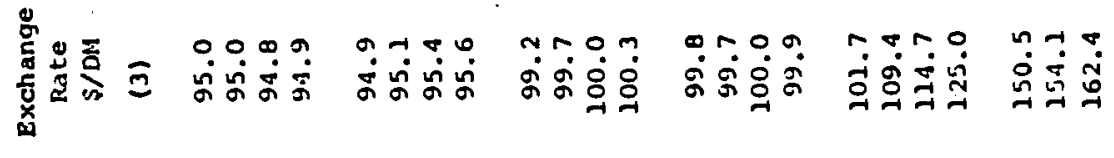

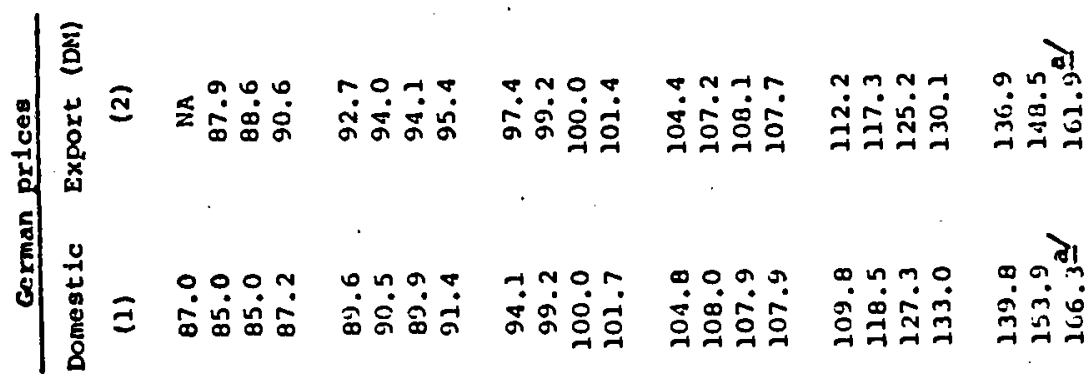


from abroad, suggested that price differentiation between various markets was more widely practiced by European suppliers than by U.S. firms and still more by Japanese exporters.

More systematic evidence about the existence of price discrimination for traded goods may be obtained by comparing the German and U.S. export price series with their corresponding wholesale price series. The price series for machinery and transport equipment (SITC 7) shown in Table 2 were constructed by combining the individual wholesale price series to an aggregate index with the aid of each country's export weights. Thus the effect of different goods composition in exports and in domestic sales has been sharply reduced. It is true that there is still room, within the 4-digit SITC categories, for compositional differences, but if markets were perfect, substitutions in production and consumption could be expected to keep the price movements of such closely related goods in close harmony. Are the ranges of variation in the export/domestic price ratio -- 6.4 percent for the U.S. (column 8) and 8.5 percent for Germany (column 7) -- sufficiently small so that we may judge export and domestic prices to move identically? One way of answering this question that has often been followed is to regress one price series against the other and to demand for a judgment in favor of identity not only an $r^{2}$ that is equal or close to one but also a constant term that is insignificantly different from zero and a slope coefficient that is insignificantly different from one. The two sets of series do not pass these tests unequivocally. The $\bar{r}^{2}$ for the annual percentage changes in the U.S. wholesale price index and the percentage changes in the U.S. export price 
index is 0.95 and the $\bar{r}^{2}$ for the corresponding German pair is 0.80. . The latter is significantly different from one at the 5 percent level. Both the U.S. and German equations satisfy the condition that the constant term be insignificantly different from zero. However, the slope coefficients in the U.S. equations are significantly different from one (at the 5 percent level) and the same is true for Germany when export prices are taken as the dependent variable though not in the opposite case.

It is in any case questionable whether reliance should be placed on a statistical test. The differences may not be large enough to be picked up by a statistical test yet be economically important. Variations of less than 10 percent in the export/domestic price ratio over a 20 year period may appear to be quite modest. Yet when account is taken of profit/sales ratios -- which for U.S. corporations producing SITC 7 products were around 4 percent in 1970 -- such swings imply large shifts in the profitability of exports and domestic sales. As we have pointed out elsewhere, both U.S. and German data provide evidence of associated changes in exports relative to domestic shipments (Kravis and Lipsey, 1977).

*The equations with $t$-values in parentheses are:

$$
\begin{aligned}
& P_{\text {USX }}=-.2432+1.1398 P_{\text {USD }} \quad \bar{r}^{2}=.95 \\
& \text { (.08) (20.1) D.W. }=2.10 \\
& P_{\text {USD }}=+.3620+0.8379 P_{\text {USX }} \quad \bar{r}^{-2}=.95 \\
& \text { (1.5) (20.1) USX D.W. }=2.10
\end{aligned}
$$

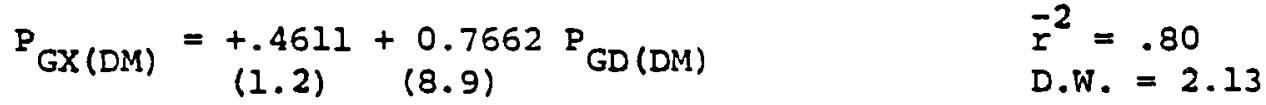

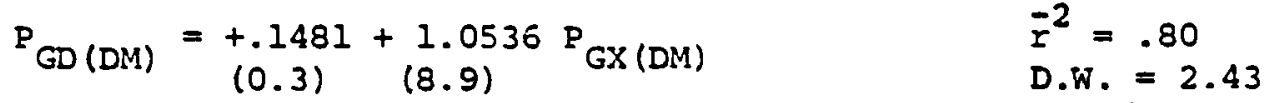

where the subscript $G$ refers to Germany, US to the U.S., D to domestic (wholesale) pricos, $Z$ to export prices, $D U$ to deutschemarks, and $\$$ to U.S. Collars. 
At a less aggregated level evidence about the existence of price discrimination between domestic and export sales of traded goods may be obtained from comparisons between export and domestic price series in an earlier paper in which changes in export prices for four countries (Germany, Japan, U.K., and U.S.) were compared with changes in domestic prices over the one- and four-year spans calculated in the Price Competitiveness book. It was found that in more than two-thirds of the cases the difference between export and domestic price changes was $4 \frac{1}{2}$ percentage points or more, far from identical changes. The correlation between the two price movements was also fairly low -- below .50 -- and it was low for each of the four countries, each time period, and each SITC division included.

For the U.S., we can draw on matched export and wholesale price indexes for ten 4-digit SITC categories covering periods of 17 to 22 years ending in 1974 . They are based on NBER (Kravis and Lipsey) indexes up to 1964 and on published BLS indexes for the subsequent years. The index numbers were expressed as year to year price relatives (the index for a given year being divided by the index for the previous year), and the export price series and wholesale price series for each of the ten 4-digit SITC categories were correlated in this form.

The results are shown in Table $3 .^{\star *}$ The coefficients of determination do not suggest identity between domestic and export price changes: 12 of the 16 are .75 or below. The ratio of the export price index to the wholesale price index strayed over a 20 percent range or greater during the nine year period in over half the

"Irving B. Kravis and Robert E. Lipsey, "International Trade Prices and Price Proxies," in Nancy D. Ruggles, Ed., The Role of the Comouter in Economic and Social Research in Latin America, NBER, 1974.

**

These results are confirmed by a more detailed matching carried out by Eliot Kalter for a shorter span of years $(1968-76)$. Kalter used published 8-digit wholesale price index and unpublished export price series for 7-digit schedule $B$ categories to make indexes for 4 - and 5-digit SITC categories. 


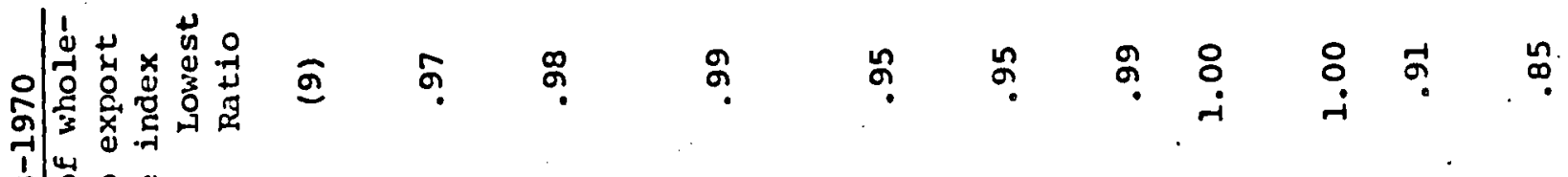

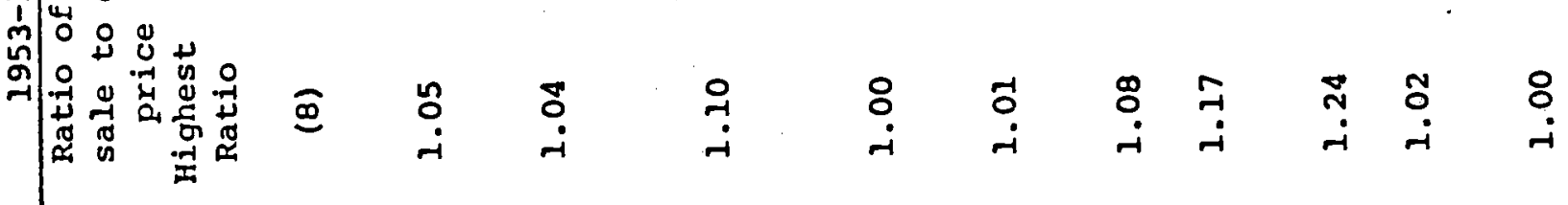
น

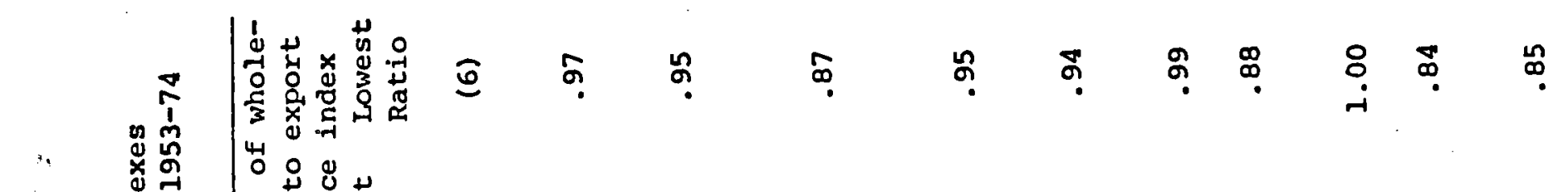

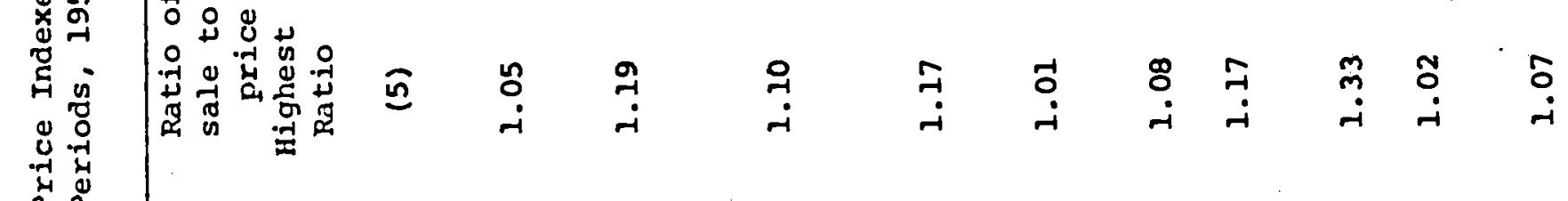

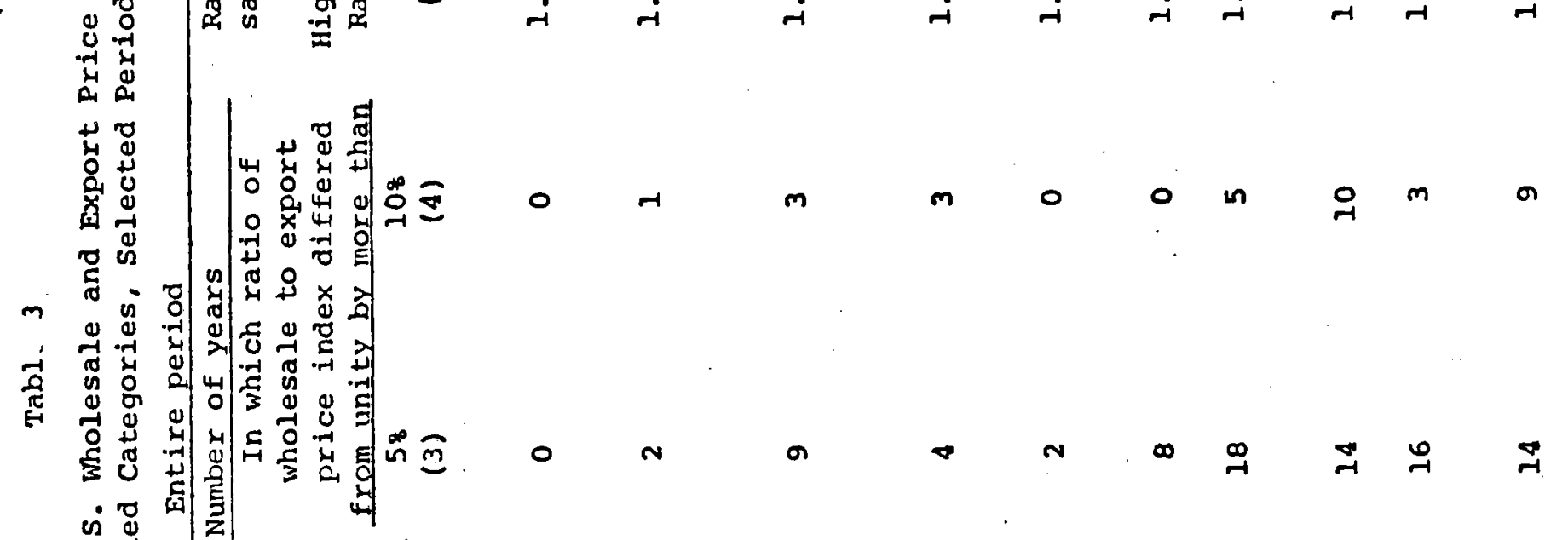

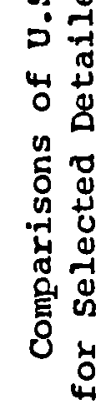

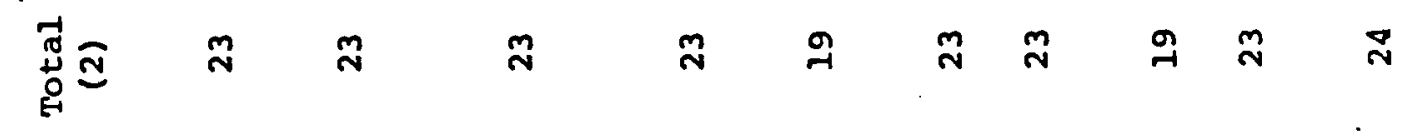

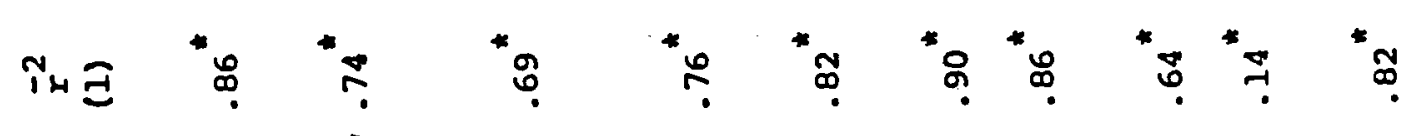

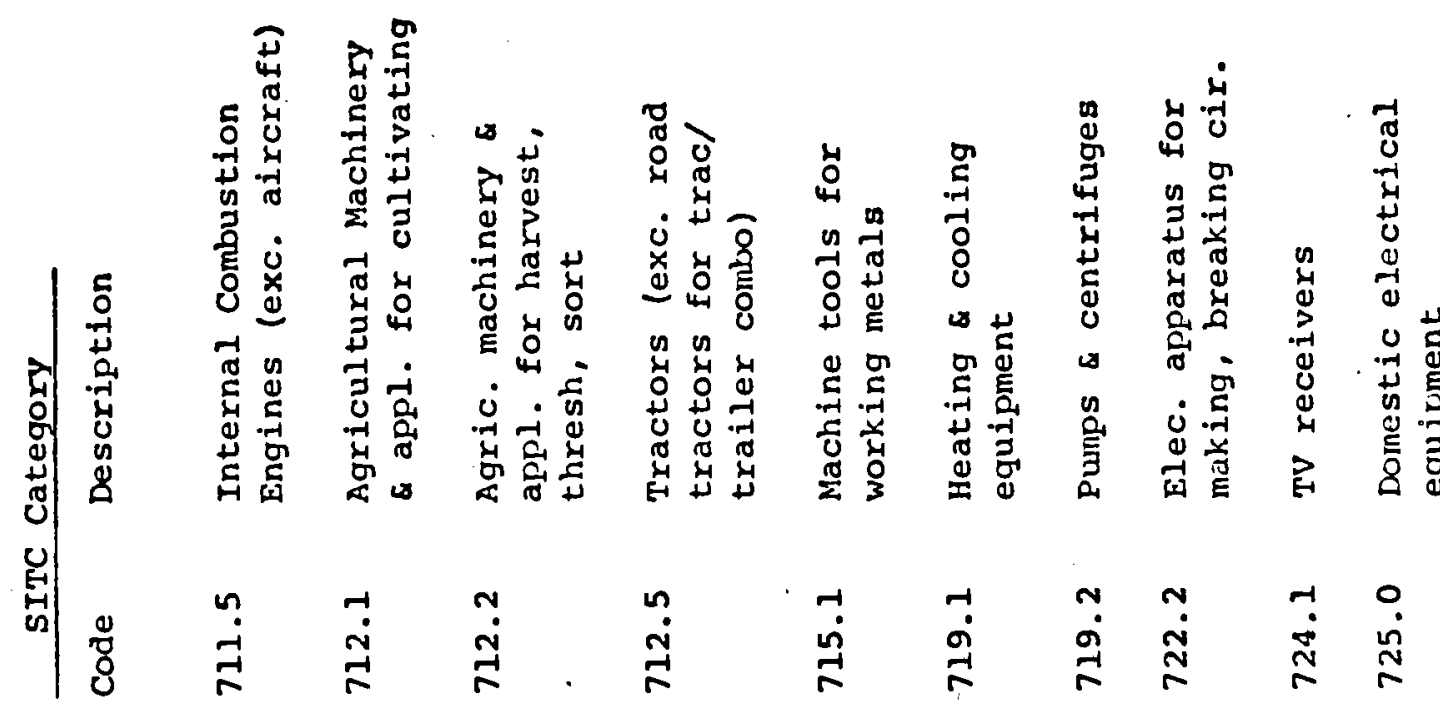


categories. Variations greater than 30 percent were found in many cascs and the lowest range was 7 percent.

Limiting the analysis to the period to 1970 and earlier when the rate of inflation was lower, produces both lower $\bar{r}^{2}$ s and a narrower range for the wholesale/export price index ratio. The highest $\bar{r}^{2}$ is .65 and 8 out of the 10 are below .50. Five of the categories reveal a wholesale/export price range over 10 percent and one of 20 percent or more.

The conclusion we come to is that the prices of U.S. exports tend to move like U.S. domestic prices but with considerable room for variation. In some product categories the association is quite close but in others there are substantial differences in time to time movements.

\section{Effects of Exchange Rate Changes}

Since export prices can and do move differently from domestic prices, the question arises whether changes in exchange rates affect the export/wholesale price relationship.

Theory of price discrimination

The theory of the firm facing separated markets is well known. Let us assune for simplicity that there are only two such markets and that there is an upward sloping long-run marginal cost curve. Assume further that the original (pre-\$ 
devaluation) foreign demand curve $\left(D_{0}^{F}\right)$ is more elastic than the domestic demand curve $\left(D_{0}^{D}\right)$. The initial domestic price is $P_{0}^{D}$ and the initial export price is $P_{0}^{F}$; these prices correspond to the marginal reveriue established by the intersection at $E_{0}$ of the marginal cost curve ( $L R M C_{0}$ ) and the combined marginal revenue curve (MRT $)$. (See Figure 1.) The U.S. dollar devaluation (or depreciation) causes a rotation in the foreign demand curve (to $D_{1}^{F}$ ) and the foreign marginal revenue curve moves from $\mathbb{M R}_{0}^{F}$ to.MR $\mathbb{M}_{1}^{F}$. The aggregate marginal revenue curve shifts from $\mathbb{M R T}_{0}$ to $\mathrm{MRT}_{1}$, and the effect is to change the equilibrium intersection of the long-run marginal cost curve and the total marginal revenue curve from $E_{0}$ to $E_{1}$. The resulting prices are $\mathrm{P}_{1}{ }^{\mathrm{F}}$ and $\mathrm{P}_{1}{ }^{\mathrm{D}}$. It can be proven that under our assumptions the dollar export price changes by a greater degree than the dollar domestic price. If it is further assumed that factor inputs are a function of the exchange rate, then the long-run marginal cost curve shifts from LRMC 0 to $I R M C_{1}$. The resulting prices are $P_{2}^{D}$ and $P_{2}^{F}$. The depreciation of the U.S. dollar, in this case, decreases the amount of optimal price discrimination between the domestic and export market.

If we had assumed instead, that the foreign demand curve was less elastic than the domestic demand curve, ceteris paribus, or if there had been an exchange rate appreciation rather than an exchange rate depreciation, then the amount of optimal price discrimination between the domestic and export market would have increased.

Still another possibility is that the oligopolist for any seller facing a sloping demand curve) keeps his foreign currency prices in each market unchanged in order to maintain his market share. This policy carried out in the face of exchange rate changes would of course produce discriminatory pricing or, if prices in different markets were already different, it would produce changes in the degree of discrimination. 
Figure 1

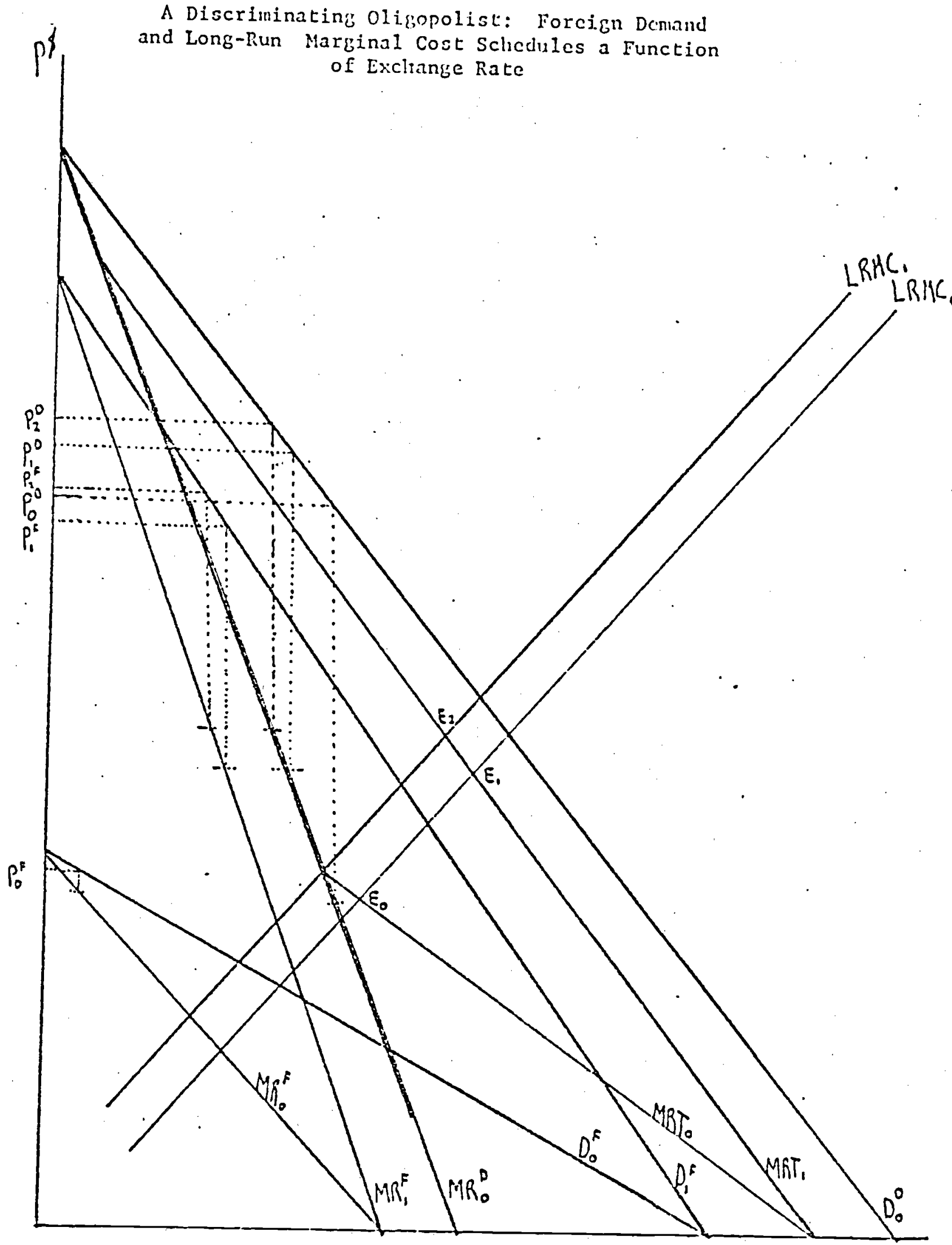


Discrimination coefficient

In testing these various expectations, we start with the following relationship:

(1) $P_{x}^{\$}=c+b_{0} P_{w P}^{\$}+b_{1} R+E$

where $\mathrm{P}_{\mathrm{X}}^{\$}$ is the $\log$ of the doliar export price relative, $C$ is the constant, $P_{\mathrm{WP}}^{\$}$ is the $\log$ of the matched dollar domestic price relative, $R$ is the log of the foreign currency price relative of the U.S. dollar and $E$ is the error term. (mhe relatives are in the form $t / t-1$ for each variable.)

The $\mathrm{P}_{\mathbf{X}}$ 's and $\mathrm{P}_{\mathrm{Wp}}$ 's represent matched export and wholesale price series for 16. 4- and 5-digit SITC categories for which series covering at least 11 years could be put together from the Kravis and Iipsey work for 1953-64 and the BIS work for the period 1964-74. Tests indicate that cata from the two sources give consistent results and thus that their linising is warranted. ive have also satisfied ourselves that the more approximate matching of export and wholesale price series that has been cone here does not Eroduce results that differ essentially from the results of a more precise matcining done by Kalter for a siorter period." The matched series for the various 4- and 5-digit categories have been poolec to estinate regression equations for SITC 7 (machinery and equigment), sITC 71 (nonelectrical machinery), SITC 72 (electrical machinery) and for 3-digit categorits with at least 25 observations."

The R's are foreign currency values of the U.S. dollai for 45 currencies, weighted for each 4- or 5-digit category by the relative importance of each

*See Irving, B. Kravis and Robert E. Lipsey, "Price Behavior in the Light of Balance of Payments Theorles," National Burcau of Vconomic Resenrch Working Paper 18/. June
1977 .

*n

Results for 4- and 5-digtt categorles are given in Appendix Table 1. 
country among U.S. export destinations in 1973. In the regressions, account has been taken of the lags between exchange rate changes and their impacts on prices by including not only the exchange rate for the current year relative to the previous year $\left(R_{t} / R_{t-1}\right)$ but also the corresponding relatives for the two immediately preceding years $\left(R_{t-1} / R_{t-2}\right.$ and $\left.R_{t-2} / R_{t-3}\right)$. For convenience these variables are shown in the tables as $R_{,} R_{-1}$ and $R_{-2}$, respectively.

The results of the regressions are set out in Table 4. The coefficients of the $R$ terms tend to be negative and the sum of the three $R$ coefficients is invariably negative. In all but agricultural machinery, the largest and most significant negative coefficient is for $R_{-2}$. The sum of the $R$ coefficients, the equivalent of $b_{1}$ in equation 1, may be interpreted as a discrimination" coefficient. That is, it shows the change in export prices holding wholesale prices constant. Putting it another way, in terms of Figure 1 , the sum of the three $R$ coefficients is equal to the ratio of $\mathrm{P}_{2}^{F} / \mathrm{P}_{0}^{F}$ to $\mathrm{P}_{2}^{\mathrm{D}} / \mathrm{P}_{0}^{\mathrm{D}}$; that is, the ratio of the export price relative $\left(P_{t} / P_{t-1}\right)$ to the corresponding wholesale price relative. Given a 10 percent U.S. dollar depreciation, for example, the equation for SITC 7 tells us that the U.S. dollar export price will rise by 1.9 percent more than the U.S. dollar wholesale price over a two to three year period. The association is negative because a depreciation (decline in foreign currency units per dollar) is equivalent to an upward shift in the foreign demand for U.S. goods (in terms of U.S. dollars) and will cause the price discriminating exporter to raise his U.S. dollar export price relative to his comestic price, while an appreciation will produce the opposite effect. In the case of a depreciation, price discrimination in which lower prices are charged exporters is apt to be reduced while in cases of appreciations price discrimination may be increased as export prices are lowered still further below home price levels. 
Table 4

Relation of U.S. Export Prices to Wholesale Prices and Exchange Rates, 1953-74*

\begin{tabular}{|c|c|c|c|c|c|c|c|c|c|}
\hline \multirow[b]{2}{*}{ SITC } & \multirow[b]{2}{*}{ Category } & & & & & & & & \\
\hline & & $\begin{array}{c}\text { Constant } \\
\text { term }\end{array}$ & $\mathrm{P}_{\mathrm{wP}}^{\$}$ & $\mathbf{R}$ & $R_{-1}$ & $R_{-2}$ & $\overline{\mathrm{R}}^{2}$ & $\begin{array}{c}\text { No. of } \\
\text { observations }\end{array}$ & $R^{\text {of }} \mathrm{R}_{-1}^{+R_{-2}}$ \\
\hline & $\begin{array}{l}\text { Machinery \& } \\
\text { equipment }\end{array}$ & $\begin{array}{c}2.3 \\
(6.5)\end{array}$ & $\begin{array}{r}.70 \\
(15.5)\end{array}$ & $\begin{array}{r}.009 \\
(3.0)\end{array}$ & $\begin{array}{l}-.08 \\
(1.8)\end{array}$ & $\begin{array}{l}-.12 \\
(2.6)\end{array}$ & .55 & 270 & -.19 \\
\hline 71 & Nonelectrical & $\begin{array}{c}2.5 \\
(6.6)\end{array}$ & $\begin{array}{r}.63 \\
(13.7)\end{array}$ & $\begin{array}{r}-.02 \\
(.5)\end{array}$ & $\begin{array}{r}-.07 \\
(1.3)\end{array}$ & $\begin{array}{l}-.08 \\
(1.7)\end{array}$ & .54 & $2 \dot{22}$ & -.17 \\
\hline 712 & Agricultural & $\begin{array}{c}1.2 \\
(1.1)\end{array}$ & $\begin{array}{r}.78 \\
(6.0)\end{array}$ & $\begin{array}{l}-.15 \\
(1.3)\end{array}$ & $\begin{array}{l}.04 \\
(.3)\end{array}$ & $\begin{array}{l}.09 \\
(.9)\end{array}$ & .47 & 63 & -.06 \\
\hline 719 & Misc. & $\begin{array}{c}4.3 \\
(7.3)\end{array}$ & $\begin{array}{r}.51 \\
(8.4)\end{array}$ & $\begin{array}{l}.07 \\
(.8)\end{array}$ & $\frac{-.21}{(2.6)}$ & $\begin{array}{l}-.31 \\
(3.4)\end{array}$ & .61 & 98 & -.45 \\
\hline 7 & Electrical & $\begin{array}{c}3.6 \\
(2.8)\end{array}$ & $\begin{array}{r}.92 \\
(6.7)\end{array}$ & $\begin{array}{l}.009 \\
(2.2)\end{array}$ & $\begin{array}{l}-.24 \\
(1.3)\end{array}$ & $\begin{array}{c}-.46 \\
(2.3)\end{array}$ & .62 & 48 & -.69 \\
\hline
\end{tabular}


Several reservations about these conclusions must be entered. One is that the last few years of the period, 1971-74, saw different exchange rate institutions and much greater variability of the exchange rate than those of the earlier years. The relatives for the SDR/dollar rate since 1970 are as follows :

$\begin{array}{ll}1971 / 70 & 99.7 \\ 1972 / 71 & 92.4 \\ 1973 / 72 & 91.1 \\ 1974 / 73 & 99.1\end{array}$

The 8 or 9 percent changes in $1972 / 71$ and $1973 / 72$ contrast with very much smaller changes in the opposite direction ( 2 or 3 percent appreciations at the outside) in the average exchange rate of the-U.S. dollar against the currencies of main trading partners for the period before 1971 .

The data thin out as we go back in time to pre-1971 years and there is but limited opportunity to explore the stability of the relationships in Table 4 . For SITC 71, there were 170 pre-1971 observations. The equation is:

$$
\text { (1.1) } \mathrm{P}_{\mathrm{X}}=\underset{(6.8)}{2.8}+\underset{(8.6)}{.50} \mathrm{P}_{\mathrm{WP}}-\underset{(1.8)}{.09} \mathrm{R}-\underset{(.5)}{.02} \mathrm{R}_{-1}+\underset{(.2)}{.01} \mathrm{R}_{-2} \cdot \overline{\mathrm{R}}^{2}=.35
$$

The equation is very similar to the SITC 71 equation in Table 4 except that it is $R$ rather than $R_{-1}$ or $R_{-2}$ that has the largest impact on export prices. Also, the sum of the coefficients of $R(\Sigma R)$ is -.10 , for the pre-1971 period, a smaller regative number than the -.17 of the Table 4 equation.

For SITC 72 only 36 observations are available for the period ending in 1970

\footnotetext{
*IMF, International Einancial Statistics, March 1977.
} 
and the results are less reliable." When SITC 71 and 72 observations are pooled, IR becomes - .05 , again smaller than the Table 4 results."

The different results found for the pre- and post-1971 data are plausible within the framework of search and information cost theory if it can be assumed that exchange rate changes during the fixed regime period, were more fully anticipated than exchange rate changes during the flexible regime. Given an exchange rate change and thus a change in the foreign country's demand for U.S. exports in terms of U.S. dollars, the oligopolist can be regarded as knowing only one point on the new demand schedule."** The less anticipated the exchange rate change, the longer and more costly the search. Thus, it would be expected that the price response lags after the post-1971 exchange rate changes are longer than the pre-1971 exchange rate changes. It is planned to investigate further these differences between the pre- and post-1971 data with respect to the timirg and magnitude of the exchange rate effects using a quarterly lag structure.

* The SITC 72 equation is as follows:

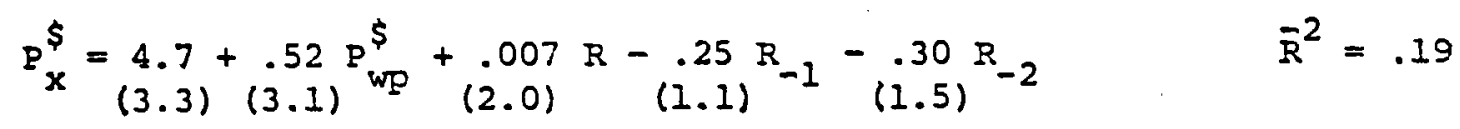

** The SITC 7 equation

$$
\mathrm{P}_{\mathrm{X}}^{\$}=\underset{(6.5)}{2.3}+\underset{(10.4)^{\mathrm{WP}}}{.56} \mathrm{P}_{(3.4)}^{.008 \mathrm{R}-.03 \mathrm{R}_{-1}-.03 \mathrm{R}_{-2}}(.6) \quad \overline{\mathrm{R}}^{2}=.36
$$

"Donald F. Gordon and Allan Hynes, "On the Theory of Price Dynamics," in Eamund S. Phelps (Ed.), Microeconomic Foundations of Employment and Inflation Theory, W.W. Norton and Co., 1970. 
We conclude tentatively that the structural relationships that we have uncovered are valid both for the period before 1971 and for later years although the sizes of the coefficients and the lag structures may differ.

A second reservation is that results apply only to one export sector, albeit an important one; machinery accounted for about one-fourth of U.S. exports in 1974. It is possible, however, that discriminatory pricing may characterize other important export sectors as for example transport equipment and chemicals which accounted for 15 percent and 9 percent of U.S. exports, respectively.

\section{Pass through coefficients}

A more technical limitation is that the equation we have fitted is open to the charge of simultaneous equation bias because $\mathrm{P}_{\mathrm{x}^{\prime}} \mathrm{P}_{\mathrm{WP}}^{\mathbf{S}}$, and $\mathrm{R}$ are all interdep. endent. One of the results of this interdependency is that the coefficient of the exchange rate in equation 1 coes not represent the extent of the pass through of an exchange rate change. Rather than reflecting the full amount of the change in the dollar export price (and thus the foreign currency export price) given an exchange rate change, the coefficient represents the change in the amount of price discrimination that is associated with the exchange rate change. That is, the coefficient of the exchange rate represents the change in the dollar export price above any change in the dollar wholesale price which may be associated with the exchange rate change. To ensure that the coefficient on the exchange rate represents the extent of the pass through rather than the change in the amount of price discrimination that is associated with an excinange rate change the procedure that is followed is outlined below.

\footnotetext{
* Survey of Current Eusiness, February 1977.
} 
First we make the domestic price variable, $\mathrm{P}_{\mathrm{wp}}^{\mathbf{p}}$, a function of domestic cost variables and the exchange rate:

$$
\text { (2) } P_{w p}^{\$}=C_{0}+a_{0} \Delta+a_{1} R+E_{0} \text {. }
$$

where $\Delta$ represents two domestic cost variables -- unit labor cost and unit non-labor cost." This enables us to form a wholesale price variable, $A P_{W P}^{\$}$, that is independent of the exchange rate variable:

$$
P_{w p}^{\$}-a_{1} R=a_{0} \Delta+\cdot E_{0}=A P_{w p}^{\$}
$$

Finally, by substituting $\mathrm{AP}_{\mathrm{Wp}}^{\$}$ into equation 1 (see page 16):

-

(3) $P_{x}^{\$}=C^{1}+A P_{W P}^{\$}+\left(b_{0} a_{1}+b_{1}\right) R+E_{1}$,

where $E_{1}=b_{0} E_{0}+E$.

The resulting coefficient on $R$ now gives the effect of $b_{1}$ from regression 1 plus the effect of $a_{1}$ from regression 2 times the effect of $b_{0}$ from regression 1 . In other words, the resulting coefficient measures, for a given exchange rate change, the full change in the export price, including the extent of the change in the wholesale price plus the difference between the change in the export price and the change in the domestic price (the extent of the discrimination caused by the exchange rate change).* of course, the procedure does not fully capture all the simultaneity involved; it ignores the influence of export prices in equation 2 , but, especially

\footnotetext{
*The current values of the $\Delta$ variables are included in the equations. The data are taken from the Monthly Labor Review. The fitted equations may be found in Appendix Table 2.

This method has been used for other purposes by Kravis and Lipsey in their Price Competitiveness in world Trade book.
}

$\star \star$ 
fo: the U.S., this may be a small source of bias relative to that affecting cquation 1. Equation 2 also ignores the possible effect of exchange rate changes on wholesale prices via the cost of imported materials.)

When equation 2 is used as a regression equation, the coefficients of the unit cost variables are highly significant and account for one-third to half of the variance in U.S. wholesale prices. The coefficients of the Rs, however, never achieve statistical significance, though they conform to expectations in that they are predominantly negative: (See Appendix Table 2.) A negative relationship between $P_{w p}^{\$}$ and $R, R_{-I}$, and $R_{-2}$ is expected both because an exchange rate change affects the total marginal revenue curve and because, if domestic goods have inported materials, an exchange rate change affects the long-run marginal cost curve (assuming that it is not horizontal).

It should be noted that a regression based on the variables in equation 3 differs from a regression based on equation 1 only in that the coefficients and t-statistics on the exchange rates differ. The $\vec{R}^{2}$ and the coefficients and $t-$ statistics on all other variables remain the same. The regressions involving $A F_{\text {wp }}^{\$}$ are therefore identical with those in Table 4 except for the sums of coefficierts of the Rs. A comparison of Tables 4 and 5 indicates that the negative size of the R's tends to be larger and the coefficients of the R's more significant when $A P_{\mathrm{wP}}^{\$}$ is used for the nonelectrical machinery categories but that the opposite is true for electrical machinery. The sum of the R's compare as follows:

\section{SITC Category}

7

71

712

719
Machinery \& equipment

Nonelectrical

ngricultural

Misc.
$\frac{\Sigma R, \text { using }}{\text { Unadjusted }} \stackrel{\$}{\text { Adjusted }}$

$-.19$

$-.20$

$-.17 \quad-.22$

$-.06 \quad-.27$

$-.45 \quad-.52$ 
Table 5

Relation of U.S. Export Prices to Adjusted wholesale Prices and Exchange Rates, 1953-74*

\begin{tabular}{|c|c|c|c|c|c|c|c|c|c|}
\hline \multirow[b]{2}{*}{ SITC } & \multirow[b]{2}{*}{ Category } & \multicolumn{5}{|c|}{ Coefficient (with t-ratio of) } & \multirow[b]{2}{*}{$\overline{\mathrm{R}}^{2}$} & \multirow[b]{2}{*}{$\begin{array}{l}\text { No. of } \\
\text { observations }\end{array}$} & \multirow{2}{*}{$\begin{array}{c}\text { Coefficie: } \\
\text { of } \\
R+R_{-1}+R_{-}=\end{array}$} \\
\hline & & $\begin{array}{c}\text { Constant } \\
\text { term }\end{array}$ & $A P_{W P}^{\$}$ & R & $\mathrm{R}_{-1}$ & $R_{-2}$ & & & \\
\hline 1. & $\begin{array}{l}\text { Machinery \& } \\
\text { equipment }\end{array}$ & $\begin{array}{l}2.3 \\
(6.5)\end{array}$ & $\begin{array}{r}.70 \\
(15.5)\end{array}$ & $\begin{array}{r}.01 \\
(3.2)\end{array}$ & $\begin{array}{l}-.09 \\
(1.8)\end{array}$ & $\begin{array}{r}-.12 \\
(2.6)\end{array}$ & .55 & 270 & -.20 \\
\hline$i 1$ & Nonelectrical & $\begin{array}{c}2.5 \\
(6.6)\end{array}$ & $\begin{array}{r}.63 \\
(13.7)\end{array}$ & $\begin{array}{r}-.07 \\
(1.3)\end{array}$ & $\begin{array}{l}-.07 \\
(1.5)\end{array}$ & $\begin{array}{l}-.08 \\
(1.6)\end{array}$ & .54 & 222 & -.22 \\
\hline 712 & Agricultural & $\begin{array}{l}1.2 \\
(1.1)\end{array}$ & $\begin{array}{r}.78 \\
(6.0)\end{array}$ & $\begin{array}{r}-.25 \\
(2.1)\end{array}$ & $\begin{array}{l}-.05 \\
(.6)\end{array}$ & $\begin{array}{l}.04 \\
(.4)\end{array}$ & .47 & 63 & -.27 \\
\hline 719 & Misc. & $\begin{array}{c}4.3 \\
(7.3)\end{array}$ & $(8.4)$ & $\begin{array}{l}.05 \\
(.6)\end{array}$ & $\begin{array}{l}-.23 \\
(2.9)\end{array}$ & $\frac{-.34}{(3.8)}$ & .61 & 98 & -.52 \\
\hline & Electrical & 3.6 & .92 & .007 & -.18 & -.40 & .62 & 48 & -.57 \\
\hline
\end{tabular}

* See note to Table 4 . See text for difference between $P_{w p}^{\$}$ of Table 4 and $A P_{W p}^{\$}$ of
this table. 
If the coefficients of the $R^{\prime} s$ are negative in equations explaining $P_{W p}^{\$}$ then the coefficients of the $R^{\prime}$ s regressions using $A_{\text {wp }}^{\$}$ will be more negative than the coefficients of the $R^{\prime} s$ in Table 4. This condition is met in the equations for SITC 71 but not for SITC 72 .

The sums of the adjusted $R$ coefficients ( $\dot{A} A R$ ) provide measures of the extent to which foreign currency export prices fell short of matching the proportionate change in the exchange rate, and thus tell us how the foreign currency price of U.S. exports changed as a result of the exchange rate change. For SITC 7 as a whole, for example, a 10 percent devaluation of the dollar (fall in the foreign purrency price of the dollar) would result in a 2.0 percent increase in dollar export prices and an 8.0 percent decline in the foreign currency prices. The "pass through" ratios may thus be obtained by adding 1 to the $\Sigma A R$; the pass through ratio was .80 for $\operatorname{SITC} 7, .78$ for $\operatorname{SITC} 71$, etc.

\section{Adjitional independent variables}

Even with these adjustments, our equations can be criticized for omitting some independent variables that may conceivably also have an influence on dollar export prices. In Table 6 , the equations in Table 5 are repeated with the addition of two independent variables.

One of the new variables, $P_{C^{\prime}}$ is intended to reflect the prices of U.S. competitors for each 4- or 5-digit SITC category. In the absence of actual price data the implicit deflators in own currency of 17 countries accounting for close to 100 percent of non-U.S. machinery exports were weighted according to the relative importance of their exports in each 4- or 5-digit category in 1973.* of course U.S. export

\footnotetext{
* A destination wcighted deflator was also used but it did not prove significant when added to equations containing $P_{c}$, perhaps because rivals were also destinations.
} 
Table 6

Relation of U.S. Export Prices to Adjusted wholesale Prices,

Exchange Rates, Implicit Deflators, of Competing Countries and Differences in Growth in GDP, 1953-74 and 1953-70*

SITC Category

Machinery \&

equipment

Nonelectrical

Agricultural

712

719 Misc.

72

71

Misc.

Electrical

$\frac{\text { Constant }}{\text { term }}$

coefficient (with t-ratio) of

$\begin{array}{lllllll}A P_{W P}^{\$} & A P_{C} & D Y & R & R_{-2} & R_{-2} & R^{2}\end{array}$
1953-74

2.3

(6.9)

$\begin{array}{lllll}.44 & -.23 \quad .02-.06-.18-61\end{array}$

$(10.9) \quad(5.3) \quad(3.2)(3.3)(1.4) \quad(3.9)$

No. of

obser-

vations

Coeffici:

of

$R+R_{-1}+R_{-}$

2.6

$\begin{array}{rr}.47 & .41 \\ (9.4) \quad(5.0)\end{array}$

(7.4)

$\begin{array}{lllllll}41 & -.25 & -.09 & -.05 & -.13 & .61\end{array}$

$\begin{array}{cc}-.05 & -.13 \\ (1.1) & (2.7)\end{array}$

$\begin{array}{lllllllll}.44 & .47 & -.07 & -.24 & -.09 & -.03 & .52\end{array}$

(2.3)

$(2.6)(2.9)$

(.5) $(2.1)$

(.8)

(.3)

3.8

(6.4)

$\begin{array}{lllllll}.42 & .36 & -.32 & .01 & -.19 & \div .32 & .66\end{array}$

$(6.8)$

$(2.6)$

$(2.8)$

(.1)

$(2.5)(3.4)$

3.1

(2.3)

.80

(4.7) (1.0)

32

$-.16 \quad .007$
$(.7)(1.7)$

$-.13$

$-.38$

(1.9)
63

$-.36$

270

$-.23$

222

$-.27$

98

$-.50$

48

$\therefore 50$

\footnotetext{
See note to Table 4, and text for explanation of variables.
} 
prices may be expected to be positively correlated with competitors' prices.

Since a strong negative relationship between $P_{C}$ and the exchange rate is to be expected, ${ }^{*}$ an adjusted $P_{C^{\prime}} A_{P_{C}}$ is formed to correct for the resulting collinearity in the same way that $\mathrm{AP}_{\mathrm{Wp}}^{\$}$ "is derived from $\mathrm{P}_{\mathrm{wP}}^{\$}$.

The other independent variable, DY, is a relative activity variable:

$$
D Y=\log \frac{\operatorname{GDPCON}_{t}}{\text { GDPCON }_{t-1}}-\log \frac{\text { WGDPCON }_{t}}{\text { WGDPCON }_{t-1}}
$$

where GDPCON $t$ is the U.S. GDP in constant dollars and WGDPCON $_{t}$ is the destination weighted GDP in constant foreign currency prices. "* A relative rise in U.S. income may be expected to raise U.S. domestic prices rather than U.S. export prices, while a relative rise of foreign incomes may be expected to have the opposite effects. The coefficient of DY should therefore be negative.

The two new variables have coefficients that generally add significantly to the explanation of U.S. export prices except in the case of electrical machinery. (See Table 6.)

A comparison of the $\sum$ Rs in Table 6 with those of Table 5 indicate that the new variables do not radically alter the outcome with respect to the pass through situation. It remains true that exporters tend initially to pass through the full effect of the change in the exchange rate but subsequently change their prices so that one-fourth to one-half of the change in the exchange rate is offset by a change in the dollar export price.

\footnotetext{
* In appreciation of the weighted average foreign currency price of the dollar (R), which is equivalent to a depreciation of the weighted average of the foreign currencies, should cause the foreign currency export price of our competitors to. cecrease. In fact a strong negative relationship does exist.

** Yearbook of National f.ccounts Statistics (New York: United Nations, 1975).
} 
The sum of the pass-through coefficients in the right hand columns of Tables 5 and 6 (for 1953-74) is greater than the sum of the discrimination coefficients in the right hand column of Table 4, as expected, for all SITC categories with the exception of SITC 72. Thus, for example, the pass through for nonelectrical machinery SITC 71 is 73 percent effective (Table 6) while the discrimination coefficient is -.23 . $^{*}$ This indicates that a 10 percent U.S. dollar depreciation will cause the dollar export price to rise by 2.7 percent while the dollar wholesale price will rise 0.4 percent over a two to three year period (the difference between the export and wholesale price indexes, 2.3 percent, is indicated by the discrimination coeficient).

For machinery as a whole a 10 percent U.S. dollar depreciation causes a 2.4 percent rise in the dollar export price. Since. the dollar wholesale price is only minimally affected by the exchange rate change, the 10 percent U.S. dollar depreciation causes a 2.4 percent differential between the home-currency domestic and export price.

\section{Conclusion}

We have shown that the law of one price does not necessarily apply to traded goods and that export prices and export price movements can be and frequently are different from domestic prices and domestic price movements. In the important machinery and equipment area competitors' prices and relative growth in GDP (U.S. versus export destination countries) affect the U.S. export/domestic price relation-

Eased on an equation containing the independent variables shown in Table 4 with the addition of $P_{C}$ and $D Y$ as independent variables, thus making it comparable to the Table 6 equation. 
ship, the former positively and the latter negatively.

Finally exchange rate changes also have an influence, a dollar depreciation tending to increase the export/domestic price ratio and an appreciation having the opposite influence. Most of the equations indicate that U.S. exporters initially "pass through" the full effect of the exchange rate changes to their foreign customers. Since the dollar export price is little affected by the exchange rate change, a depreciation of the dollar is initially passed on in the form of proportionately lower export prices in terms of foreign currency. Exporters gradually adjust their export prices to conform to the optimal relationship between home and foreign prices by raising dollar export prices. By the end of two to three years, the sum of the $R$ coefficients suggests, one-fourth to onehalf of a depreciation has been offset by dollar export price increases, and the reamining three-quarters to one-half passed on to foreign purchasers in the form of lower foreign currency prices of U.S. exports. 
Appendix

Empirical Results of Individual 4- and 5-digit SITC Products

The results of the regression:

(1) $\mathrm{P}_{\mathrm{x}}^{\mathrm{S}}=\mathrm{C}+\mathrm{b}_{1} \mathrm{P}_{\mathrm{wp}}^{\mathrm{S}}+\mathrm{b}_{2} \mathrm{R}+\mathrm{b}_{3} \mathrm{R}_{-1}+\mathrm{b}_{4} \mathrm{R}_{-2}$

for each of the individual 4- and 5-digit SITC goods are listed in Appendix Table 1. Fully specified regressions were not run due to the limited number of observations for most of the individual products. Eleven of the 16 categories have sums of the $R$ coefficients that are negative and the simple average of the sums for 16 products is -.26 . This compares to $=-.19$ for the equivalent pooled regression for SITC 7. 
Appendix Table 1 SITC7: Individual Foule-and Five-Digit

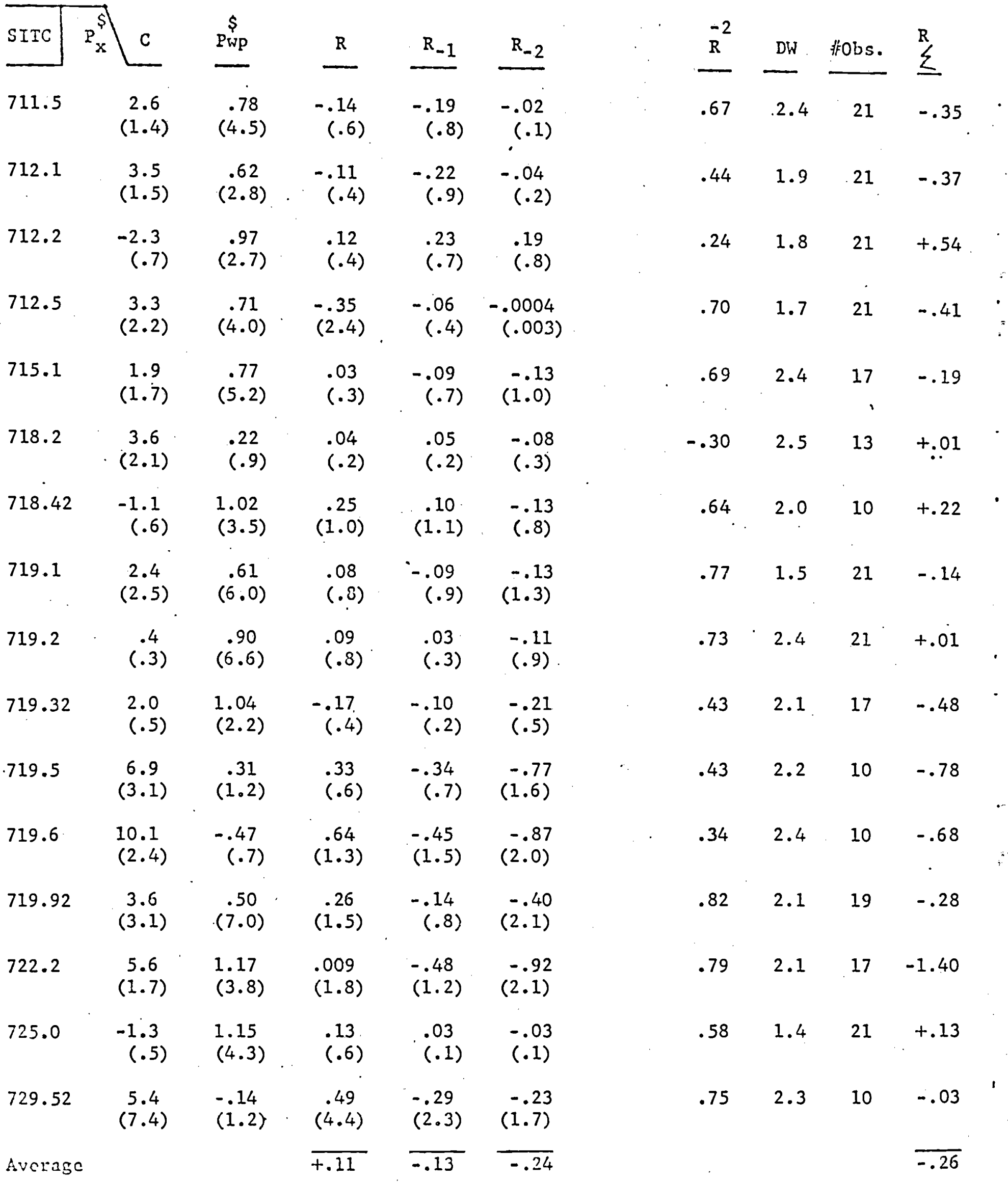


Appendix Table 2

Relationship of wholesale Price to Cost Factors and Exchange Rates, 1953-74*

\begin{tabular}{|c|c|c|c|c|c|c|c|c|c|}
\hline \multirow[b]{2}{*}{ SITC } & \multirow[b]{2}{*}{ Category } & \multicolumn{6}{|c|}{ Coefficient (with t-ratio) of } & \multirow[b]{2}{*}{$\overline{\mathrm{R}}^{2}$} & \multirow[b]{2}{*}{$\begin{array}{c}\text { No. of } \\
\text { Observations }\end{array}$} \\
\hline & & $\begin{array}{l}\text { onstant } \\
\text { term }\end{array}$ & $\begin{array}{l}\text { Unit } \\
\text { labor } \\
\text { cost }\end{array}$ & $\begin{array}{r}\text { Unit } \\
\text { non-la } \\
\text { cost }\end{array}$ & bor $R$ & $\mathbf{R}_{-1}$ & $R_{-2}$ & & \\
\hline 7 & $\begin{array}{l}\text { Machinery \& } \\
\text { equipment }\end{array}$ & $\begin{array}{l}.21 \\
(.3)\end{array}$ & $\begin{array}{c}.68 \\
(9.6)\end{array}$ & $\begin{array}{c}.28 \\
(4.4)\end{array}$ & $\begin{array}{l}.0009 \\
(.2)\end{array}$ & $\begin{array}{r}-.003 \\
(.05)\end{array}$ & $\begin{array}{l}-.00006 \\
(.001)\end{array}$ & .34 & 270 \\
\hline 71 & Nonelectrical & $\begin{array}{c}.80 \\
(1.0)\end{array}$ & $\begin{array}{l}.65 \\
(8.6)\end{array}$ & $\begin{array}{c}.26 \\
(3.8)\end{array}$ & $\begin{array}{l}-.07 \\
(1.1)\end{array}$ & $\begin{array}{r}-.01 \\
(.2)\end{array}$ & $\begin{array}{l}.003 \\
(.05)\end{array}$ & .35 & 222 \\
\hline 712 & Agricultural & $\begin{array}{c}3.7 \\
(3.6)\end{array}$ & $\begin{array}{l}.39 \\
(4.2)\end{array}$ & $\begin{array}{c}.14 \\
(1.7)\end{array}$ & $\begin{array}{l}-.13 \\
(1.2)\end{array}$ & $\begin{array}{l}-.13 \\
(1.3)\end{array}$ & $\begin{array}{l}.06 \\
(.8)\end{array}$ & .47 & 63 \\
\hline 719 & Misc. & $\begin{array}{l}.57 \\
(.4)\end{array}$ & $\begin{array}{c}.72 \\
(4.7)\end{array}$ & $\begin{array}{c}.31 \\
(2.4)\end{array}$ & $\begin{array}{r}-.04 \\
(.3)\end{array}$ & $\begin{array}{r}-.04 \\
(.3)\end{array}$ & $\begin{array}{r}-.07 \\
(.5)\end{array}$ & .29 & 98 \\
\hline 72 & Electrical & $\begin{array}{l}-.88 \\
(.4)\end{array}$ & $\begin{array}{c}.73 \\
(4.1)\end{array}$ & $\begin{array}{c}.32 \\
(2.2)\end{array}$ & $\begin{array}{l}-.002 \\
(.5)\end{array}$ & $\begin{array}{l}.06 \\
(.3)\end{array}$ & $\begin{array}{l}.07 \\
(.4)\end{array}$ & .31 & 48 \\
\hline
\end{tabular}

* See note to Table 4. 